\title{
Clinical features, comorbidity, and cognitive impairment in elderly bipolar patients
}

\author{
This article was published in the following Dove Press journal: \\ Neuropsychiatric Disease and Treatment \\ 17 May 2016 \\ Number of times this article has been viewed
}

\author{
Ida Vikan Rise' \\ Josep Maria Haro ${ }^{2-4}$ \\ Bjørn Gjervan ${ }^{5,6}$
}

'Department of Psychiatry, Sorlandet Hospital, Arendal, Norway; ${ }^{2}$ Research Unit, Parc Sanitari Sant Joan de Déu, Sant Boi de Llobregat, Spain; ${ }^{3}$ Faculty of Medicine, Universitat de Barcelona, Barcelona, Spain; ${ }^{4} \mathrm{CIBERSAM}$ (Centro de Investigación Biomédica En Red de Salud Mental), Madrid, Spain; ${ }^{5}$ Department of Psychiatry, North-Trondelag Hospital Trust, Levanger, Norway; ${ }^{6}$ Department of Medicine, Institute of Neuromedicine, Norwegian University of Science and Technology, Trondheim, Norway
Correspondence: Ida Vikan Rise Sørlandet Hospital, Psykiatrisk Sykehusavdeling (Arendal), Postboks 416, 4604 Kristiansand, Norway

Tel +47370l 4400

Email theida@gmail.com
Introduction: Data specific to late-life bipolar disorder (BD) are limited. Current research is sparse and present guidelines are not adapted to this group of patients.

Objectives: We present a literature review on clinical characteristics, comorbidities, and cognitive impairment in patients with late-life BD. This review discusses common comorbidities that affect BD elders and how aging might affect cognition and treatment.

Methods: Eligible studies were identified in MedLine by the Medical Subject Headings terms "bipolar disorder" and "aged". We only included original research reports published in English between 2012 and 2015.

Results: From 414 articles extracted, 16 studies were included in the review. Cardiovascular and respiratory conditions, type II diabetes, and endocrinological abnormalities were observed as highly prevalent. BD is associated with a high suicide risk. Bipolar elderly had an increased risk of dementia and performed worse on cognitive screening tests compared to age-matched controls across different levels of cognition. Despite high rates of medical comorbidity among bipolar elderly, a systematic under-recognition and undertreatment of cardiovascular disease have been suggested.

Conclusion: There was a high burden of physical comorbidities and cognitive impairment in late-life BD. Bipolar elderly might be under-recorded and undertreated in primary medical care, indicating that this group needs an adapted clinical assessment and specific clinical guidelines need to be established.

Keywords: bipolar disorder, aged, comorbidity, cognition, impairment, treatment

\section{Introduction}

Bipolar disorder (BD) is a major affective disorder marked by recurrent/cyclical episodes of mania/hypomania and depression as described in the Diagnostic and Statistical Manual of Mental Disorders, 5th edition. ${ }^{1}$ The subtypes of BD include bipolar disorder I (BD-I) and bipolar disorder II (BD-II). Patients with BD-I experience manic episodes and nearly always experience major depressive and hypomanic episodes whereas BD-II is marked by at least one hypomanic episode, at least one major depressive episode, and the absence of manic episodes. To satisfy a clinical diagnosis of BD, the abnormal mood episodes should have a detrimental effect on the social and occupational functioning of the individual. Late-life BD or geriatric BD usually refers to patients older than 60 years with BD. However, some authorities use an age cut-off of 50, 55, or 65 years. Late-life BD includes both patients diagnosed in their younger years (early-onset BD) and in late-life, often called late-onset BD. Due to no validated age-at-onset threshold, this definition remains arbitrary. ${ }^{2}$ One out of four bipolar patients is reported to be older than 60 years. ${ }^{3}$ A systematic review of the prevalence of BD in population-based studies revealed heterogeneous findings concerning the prevalence of $\mathrm{BD}$, ranging from

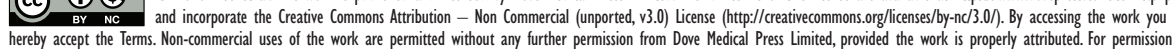
for commercial use of this work, please see paragraphs 4.2 and 5 of our Terms (https://www.dovepress.com/terms.php). 
$0.1 \%$ to $7.5 \% .{ }^{4}$ Community surveys in 14 countries found that the lifetime prevalence of BD was $2.8 \%,{ }^{5}$ while another set of community surveys in eleven countries found a considerably lower lifetime prevalence of BD, with rates of BD-I and BD-II reported to be $0.6 \%$ and $0.4 \%$, respectively. ${ }^{6}$ In both sexes, the pattern of bipolar diagnoses has been reported to increase similarly over the years until middle age where it was observed to reach a plateau. ${ }^{7}$ The considerable variety of prevalence rates in $\mathrm{BD}$ may be related to the consideration of subthreshold criteria upon diagnosis, differences in study design, and psychiatric assessment. The annual incident rate has been reported to be 30 per 100,000 capita. $^{7}$ The mean standardized mortality ratio for BD has been reported to be 2.00 with a reduced life expectancy of 9 years among bipolar patients. ${ }^{7}$ The relative risk of all-cause mortality was reported to be 2.9 in the age group 65-75 years and highest among adults under 45 years (8.95), suggesting that the younger population with BD have a specially reduced life expectancy compared to the general population. ${ }^{7}$ An elevated leukocyte count often seen in acute affective episode has previously been suggested to increase the risk of early natural death from all causes in bipolar patients, independent of smoking and other cardiovascular risk factors. ${ }^{8}$

Due to physiological age-related changes, different pharmacodynamics and kinetics, cognitive impairment, medical comorbidity and concomitant medication, long-term treatment with mood stabilizers and their potential negative effect, older patients may have different clinical characteristics and treatment response than the younger bipolar population. ${ }^{9,10}$ Late-life BD has been associated with multiple medical comorbidities, and the dominating conditions observed are type II diabetes, respiratory and cardiovascular conditions, and other endocrine abnormalities. ${ }^{10}$ It has been suggested that medical comorbidity accounts for $40 \%-70 \%$ of personal and societal costs of BD. ${ }^{11}$ Yet, it is not clear whether medical disorders among individuals with BD are truly comorbid disorders, or a consequence of treatment, or a combination of both. ${ }^{12}$ Lifestyle characteristics such as smoking, diet, substance abuse, and metabolic abnormalities related to psychotropic drug use contribute to medical complication and poor prognosis. ${ }^{13}$ Psychiatric comorbidities have previously been reported to be less prevalent than physical comorbidities, and the prevalence has appeared to be lower in elderly bipolar patients compared to the younger BD population, with anxiety and substance abuse disorders being the most common concurrent psychiatric illnesses. ${ }^{10}$ There are however some limitations to be considered regarding this literature, as no prospective studies have evaluated this topic and most studies have been small, retrospective, and conducted only on hospitalized patients. ${ }^{10}$

There seems to be an increase in the amount of published research on this topic over the past decade. ${ }^{9}$ Emerging research suggests that $\mathrm{BD}$ is not solely an illness of mood but that it affects multiple domains impacting overall functioning, considering it to be a multisystem condition in which medical comorbidity, cognitive impairment, and early mortality may have underlying common mechanistic elements. To our knowledge, all of the reviews regarding this topic consider there is a lack of adapted assessment for this group of patients, as their treatment is based on guidelines drawn up for younger patients with BD. The aim of the study was to identify specific clinical characteristics in individuals older than 60 years with BD and to gain more knowledge of how aging in these individuals might affect cognitive function and treatment.

\section{Methods}

PubMed/MedLine was searched for studies about elderly ( $>60$ years) patients with BD and their characteristics. Selected articles were those with Medical Subject Headings term "Bipolar Disorder", restricted to Medical Subject Headings Major Topic, and "aged". The search was limited to studies published in the period January 2012 till January 2015 in order to obtain the most recent scientific articles. The database was searched for original research reports published in English from the period November 2014 to January 2015. Titles and abstracts from the obtained articles were reviewed and all retrieved papers were screened to meet the following inclusion criteria:

- Studies including patients aged 60 or older or studies with participants of any age, only if separate data were reported for the patients aged 60 years and older.

- Minimum sample size of $\mathrm{N}=30$, as small samples may reduce the likelihood that findings reflect a true effect. $^{14}$

- A clear definition of BD with diagnostic criteria of Diagnostic and Statistical Manual of Mental Disorders-IV and $-\mathrm{V}$, and ICD-9 and -10 .

\section{Search results}

The data search by keywords yielded 414 potentially eligible articles. A total of 398 articles were excluded, resulting in 16 studies meeting the inclusion criteria. Reasons for exclusion were no data specific to patients above 60 years. The characteristics of the included studies are listed in Table 1. We identified six articles that reported medical 
Table I An overview of the characteristics of the included studies

\begin{tabular}{|c|c|c|c|c|c|}
\hline Authors & Design & Sample & $\begin{array}{l}\text { Measurements of } \\
\text { outcome }\end{array}$ & Objectives & Results \\
\hline $\begin{array}{l}\text { Aprahamian } \\
\text { et } \mathrm{al}^{21}\end{array}$ & $\begin{array}{l}\text { Cross- } \\
\text { sectional }\end{array}$ & $\begin{array}{l}\mathrm{N}=86 \text { patients } \\
\text { with } \mathrm{BD} \\
\text { (mean age: } 69.2 \text { ) }\end{array}$ & $\begin{array}{l}\text { MMSE, } \\
\text { VFT, and CDT }\end{array}$ & $\begin{array}{l}\text { To investigate the } \\
\text { performance on } \\
\text { cognitive screening } \\
\text { tests in a sample of } \\
\text { older adults with } \mathrm{BD} \text {, } \\
\text { as compared to non- } \\
\mathrm{BD} \text { subjects }\end{array}$ & $\begin{array}{l}\text { Nondemented patients with BD } \\
\text { had a slightly worse global cognitive } \\
\text { performance as compared with } \\
\text { healthy controls and patients } \\
\text { with cognitive impairment but no } \\
\text { dementia. } \\
\text { Patients with BD performed worse } \\
\text { on the VFT, both in the normal } \\
\text { cognition range and in the dementia } \\
\text { range. }\end{array}$ \\
\hline $\begin{array}{l}\text { Birgenheir } \\
\text { et } \mathrm{al}^{17}\end{array}$ & $\begin{array}{l}\text { Cross- } \\
\text { sectional }\end{array}$ & $\begin{array}{l}\mathrm{N}=12,857 \\
\text { patients with } \mathrm{BD} \\
\geq 65 \text { years }\end{array}$ & $\begin{array}{l}\text { Primary dependent } \\
\text { variables were seven } \\
\text { specific pain conditions: } \\
\text { arthritis, back pain, } \\
\text { chronic noncancer pain, } \\
\text { migraine headache, } \\
\text { tension, and other } \\
\text { headache, psychogenic and } \\
\text { neuropathic }\end{array}$ & $\begin{array}{l}\text { To assess the rates of } \\
\text { chronic, noncancer } \\
\text { pain conditions in } \\
\text { patients with BD } \\
\text { within the Veterans } \\
\text { Health Administration } \\
\text { System }\end{array}$ & $\begin{array}{l}\text { Noncancer pain conditions occur } \\
\text { in elevated rates among patients } \\
\text { with BD. } \\
\text { After adjusting for other } \\
\text { demographic and patient } \\
\text { factors, patients with BD had } \\
\text { significantly higher odds of having } \\
\text { any pain condition (OR I.83) } \\
\text { as well as every specific pain } \\
\text { condition (aORs ranging from } \\
\text { I.50 to 6.24). }\end{array}$ \\
\hline Ciulla et a $\left.\right|^{19}$ & $\begin{array}{l}\text { Cross- } \\
\text { sectional }\end{array}$ & $\begin{array}{l}\mathrm{N}=32 \text { patients } \\
\text { with } \mathrm{BD} \\
\geq 60 \text { years }\end{array}$ & $\begin{array}{l}\text { Prevalence of ideation, } \\
\text { attempts, and suicide risk } \\
\text { measured by MINIplus }\end{array}$ & $\begin{array}{l}\text { To examine prevalence } \\
\text { and level of suicide risk } \\
\text { and its associations } \\
\text { with sociodemographic } \\
\text { factors and mood } \\
\text { disorders }\end{array}$ & $\begin{array}{l}\text { BD was associated with a high } \\
\text { suicide risk. The increased suicide } \\
\text { risk was reported for those with } \\
\text { and without a current mood } \\
\text { episode. }\end{array}$ \\
\hline $\begin{array}{l}\text { Clements } \\
\text { et } \mathrm{al}^{20}\end{array}$ & $\begin{array}{l}\text { Cross- } \\
\text { sectional }\end{array}$ & $\begin{array}{l}N=156 \text { patients } \\
\text { with } B D \\
\geq 65 \text { years }\end{array}$ & Suicide database $\mathrm{NCl}$ & $\begin{array}{l}\text { To describe the } \\
\text { frequency, trends } \\
\text { over time, and } \\
\text { characteristics of those } \\
\text { with BD who died by } \\
\text { suicide in England }\end{array}$ & $\begin{array}{l}\text { Factors such as alcohol } \\
\text { dependence/misuse, personality } \\
\text { disorder, depressive illness, and } \\
\text { current/recent in-patient admission } \\
\text { seemed to characterize a high-risk } \\
\text { group. }\end{array}$ \\
\hline $\begin{array}{l}\text { Gildengers } \\
\text { et } \mathrm{a}^{25}\end{array}$ & $\begin{array}{l}\text { Cross- } \\
\text { sectional study }\end{array}$ & $\begin{array}{l}\mathrm{N}=43 \text { patients } \\
\text { with } \mathrm{BD} \\
\geq 65 \text { years } \\
\text { (mean age: } 74.0 \text { ) }\end{array}$ & $\begin{array}{l}\text { 2I well-established } \\
\text { and validated individual } \\
\text { tests measuring multiple } \\
\text { cognitive domains }\end{array}$ & $\begin{array}{l}\text { To examine the overall } \\
\text { patterns of cognitive } \\
\text { function in patients } \\
\text { with } B D \text { and MDD }\end{array}$ & $\begin{array}{l}\text { Both subjects with BD and } \\
\text { MDD were impaired across all } \\
\text { cognitive domains compared to } \\
\text { controls, most prominently in } \\
\text { information processing speed and } \\
\text { executive function. Despite the } \\
\text { protective effects of having higher } \\
\text { education and lower vascular } \\
\text { burden, BD subjects were more } \\
\text { impaired across all cognitive } \\
\text { domains compared with MDD } \\
\text { subjects. }\end{array}$ \\
\hline $\begin{array}{l}\text { Goldstein } \\
\text { et } \mathrm{al}^{16}\end{array}$ & Cohort study & $\begin{array}{l}\mathrm{N}=64 \text { patients } \\
\text { with } \mathrm{BD} \\
\geq 65 \text { years }\end{array}$ & $\begin{array}{l}\text { Obesity was defined as } \\
\text { having a BMI of } \geq 30 \mathrm{~kg} / \mathrm{m}^{2} . \\
\text { Respondents were asked } \\
\text { about the presence of } \\
\text { eleven medical conditions. } \\
\text { Short Form } 12 \text { version } 2 \text {, a } \\
\text { measure of health-related } \\
\text { quality of life in large } \\
\text { populations, was used }\end{array}$ & $\begin{array}{l}\text { To examine if obesity } \\
\text { is associated with an } \\
\text { increased medical and } \\
\text { psychiatric burden } \\
\text { in BD }\end{array}$ & $\begin{array}{l}\text { Obesity independently predicts the } \\
\text { accumulation of medical conditions } \\
\text { among adults with } \mathrm{BD} \text {. } \\
\text { Obese subjects with BD remained } \\
\text { significantly more likely to report } \\
\text { any new-onset medical condition } \\
\text { (OR 2.32), new-onset hypertension } \\
\text { (OR I.8I), arthritis (OR I.64), } \\
\text { physician-diagnosed diabetes } \\
\text { (OR 6.98), and hyperlipidemia } \\
\text { (OR 2.32). }\end{array}$ \\
\hline
\end{tabular}


Table I (Continued)

\begin{tabular}{|c|c|c|c|c|c|}
\hline Authors & Design & Sample & $\begin{array}{l}\text { Measurements of } \\
\text { outcome }\end{array}$ & Objectives & Results \\
\hline $\begin{array}{l}\text { Kodesh } \\
\text { et } \mathrm{al}^{7}\end{array}$ & $\begin{array}{l}\text { Historical } \\
\text { cohort study }\end{array}$ & $\begin{array}{l}\mathrm{N}=I, 52 \mathrm{I} \\
\text { patients with } \mathrm{BD} \\
\geq 65 \text { years }\end{array}$ & $\begin{array}{l}\text { Database containing } \\
\text { demographic information, } \\
\text { medical diagnoses, } \\
\text { laboratory results, } \\
\text { medications, treatment } \\
\text { documentation, and } \\
\text { information regarding } \\
\text { medical encounters. The } \\
\text { database forms the basis } \\
\text { for merging separate } \\
\text { registers of patients with } \\
\text { different chronic diseases } \\
\text { (CVD, DM, hypertension, } \\
\text { and cancer) }\end{array}$ & $\begin{array}{l}\text { To investigate the } \\
\text { epidemiology of } \\
\text { schizophrenia and } \\
\text { bipolar affective } \\
\text { disorder among } \\
\text { adults, and to assess } \\
\text { their comorbidity and } \\
\text { mortality compared to } \\
\text { the general population }\end{array}$ & $\begin{array}{l}\text { The crude prevalence rate of BD } \\
\text { was } 3 \text { per I,000 capita. The annual } \\
\text { incidence rate of BD was } 30 \text { per } \\
\text { I00,000 capita. Compared to the } \\
\text { general population, BD patients had } \\
\text { a 9-year shorter life expectancy. } \\
\text { They were also more likely to } \\
\text { be diagnosed with DM (OR I.6). } \\
\text { Results showed that both bipolar } \\
\text { individuals had a slightly higher } \\
\text { age-adjusted risk of having cancer, } \\
\text { diabetes, and hypertension } \\
\text { compared to the general } \\
\text { population. }\end{array}$ \\
\hline $\begin{array}{l}\text { Meesters } \\
\text { et } \mathrm{al}^{26}\end{array}$ & $\begin{array}{l}\text { Cross- } \\
\text { sectional }\end{array}$ & $\begin{array}{l}\mathrm{N}=74 \text {, patients } \\
\text { with BD type I } \\
\text { (mean age: } 70 \text { ) }\end{array}$ & $\begin{array}{l}\text { Several tests spanning } \\
\text { four cognitive domains; } \\
\text { attention/working } \\
\text { memory, verbal memory, } \\
\text { executive function, and } \\
\text { verbal fluency }\end{array}$ & $\begin{array}{l}\text { To investigate } \\
\text { differences in cognitive } \\
\text { impairment between } \\
\text { schizophrenia and BD }\end{array}$ & $\begin{array}{l}\text { Patients with schizophrenia and } \\
\text { BD-I were impaired compared to } \\
\text { healthy controls, with mostly large } \\
\text { effect sizes for verbal memory and } \\
\text { verbal fluency, but with smaller } \\
\text { effect sizes for the domain of } \\
\text { attention/working memory. }\end{array}$ \\
\hline $\begin{array}{l}\text { van Melick } \\
\text { et } \mathrm{al}^{28}\end{array}$ & $\begin{array}{l}\text { Retrospective } \\
\text { study }\end{array}$ & $\begin{array}{l}\mathrm{N}=288 \text { patients } \\
\text { with } \mathrm{BD} \text { and } \\
\geq 60 \text { years }\end{array}$ & $\begin{array}{l}\text { VGR, } T_{i} T R, T_{b} T R, T_{a} T R, \\
\text { and annual number of } \\
\text { measurements were } \\
\text { considered a proxy for } \\
\text { instability }\end{array}$ & $\begin{array}{l}\text { To investigate age as a } \\
\text { determinant of serum } \\
\text { lithium concentration } \\
\text { instability during } \\
\text { both the titration and } \\
\text { maintenance phase of } \\
\text { lithium treatment }\end{array}$ & $\begin{array}{l}\text { Age was not a determinant of } \\
\text { serum lithium concentration } \\
\text { instability. VGR and } T_{i} T R, T_{a} T R \text {, } \\
\text { and } T_{b} T R \text { did not differ significantly } \\
\text { between the reference group and } \\
\text { the two oldest age groups (60-69) } \\
\text { and ( } \geq 70) \text {. The annual number } \\
\text { of lithium serum concentration } \\
\text { measurements was higher in } \\
\text { the oldest age groups, and this } \\
\text { difference was significant }(P<0.05) \text {. }\end{array}$ \\
\hline $\begin{array}{l}\text { Montes } \\
\text { et } \mathrm{al}^{2}\end{array}$ & $\begin{array}{l}\text { Cross- } \\
\text { sectional }\end{array}$ & $\begin{array}{l}\mathrm{N}=69 \text {, patients } \\
\text { with BD } \\
\geq 65 \text { years }\end{array}$ & $\begin{array}{l}\text { Sociodemographic } \\
\text { and treatment } \\
\text { (pharmacological and } \\
\text { nonpharmacological) } \\
\text { characteristics. Measures } \\
\text { of severity and disability }\end{array}$ & $\begin{array}{l}\text { To examine } \\
\text { demographic, clinical, } \\
\text { and treatment } \\
\text { correlates of BD-I vs } \\
\text { BD-Il and patients with } \\
\text { early onset versus late } \\
\text { onset of the illness }\end{array}$ & $\begin{array}{l}\text { Geriatric BD has similar clinical } \\
\text { characteristics with those of younger } \\
\text { ages, and these do not seem to } \\
\text { greatly differ with BD subtype or } \\
\text { age of onset. The patients were } \\
\text { receiving a mean of three different } \\
\text { psychotropic medications. The } \\
\text { prevalence of lifetime psychiatric } \\
\text { comorbidity (I8.8\%) was significantly } \\
\text { lower than the prevalence of } \\
\text { physical comorbidity ( } 8 \text { I.2\%). } \\
\text { The most prevalent physical } \\
\text { comorbidities were arterial } \\
\text { hypertension ( } 37.7 \% \text { ), DM ( } 24.6 \%) \text {, } \\
\text { and hypothyroidism (I } 3 \%) \text {. }\end{array}$ \\
\hline $\begin{array}{l}\text { Rybakowski } \\
\text { et } \mathrm{al}^{27}\end{array}$ & $\begin{array}{l}\text { Cross- } \\
\text { sectional }\end{array}$ & $\begin{array}{l}\mathrm{N}=120 \text { patients } \\
\text { with } \mathrm{BD}, 90 \\
\text { of them who } \\
\text { were exposed } \\
\text { to lithium (mean } \\
\text { age: } 60 \pm 10 \text { ) }\end{array}$ & $\begin{array}{l}\text { Measures of kidney } \\
\text { functions; urine examina- } \\
\text { tion with specific gravity } \\
\text { evaluation, serum creatine } \\
\text { concentration, eGFR } \\
\text { evaluation, and two markers } \\
\text { of kidney injury: serum } \\
\text { concentration of neutrophil } \\
\text { NGAL and urinary } \\
\text { concentration of } \beta 2-M G\end{array}$ & $\begin{array}{l}\text { To compare the novel } \\
\text { markers of kidney } \\
\text { injury between a group } \\
\text { of long-term lithium- } \\
\text { treated bipolar patients } \\
\text { and age-matched } \\
\text { bipolar patients not } \\
\text { exposed to lithium }\end{array}$ & $\begin{array}{l}\text { Lithium treatment causes an } \\
\text { impairment of kidney function } \\
\text { reflected also by abnormal levels } \\
\text { of novel markers of kidney injury. } \\
\text { Urinary } 32-M G \text { seemed to be a } \\
\text { better predictor than serum NGAL } \\
\text { in lithium-treated patients because } \\
\text { it showed multiple clinical and } \\
\text { biochemical correlations, especially } \\
\text { in men. }\end{array}$ \\
\hline
\end{tabular}


Table I (Continued)

\begin{tabular}{|c|c|c|c|c|c|}
\hline Authors & Design & Sample & $\begin{array}{l}\text { Measurements of } \\
\text { outcome }\end{array}$ & Objectives & Results \\
\hline $\begin{array}{l}\text { Schouws } \\
\text { et } \mathrm{al}^{23}\end{array}$ & Cohort study & $\begin{array}{l}\mathrm{N}=65 \\
\text { patients with } \mathrm{BD} \\
>60 \text { (mean age: } \\
68.4 \text { ) }\end{array}$ & $\begin{array}{l}\text { MMSE was used to provide } \\
\text { an overall assessment } \\
\text { of cognitive function. } \\
\text { Several neuropsychological } \\
\text { tests grouped into four } \\
\text { cognitive domains were } \\
\text { used: attention, learning } \\
\text { and memory, executive } \\
\text { functioning, and verbal } \\
\text { fluency }\end{array}$ & $\begin{array}{l}\text { To investigate } \\
\text { neurocognitive } \\
\text { performance in } \\
\text { BD over a period of } \\
2 \text { years }\end{array}$ & $\begin{array}{l}\text { At baseline and at follow-up, } \\
\text { patients with BD performed worse } \\
\text { on all neurocognitive measures } \\
\text { compared to the healthy elderly } \\
\text { group. However, they did not have } \\
\text { greater cognitive decline compared } \\
\text { to the healthy controls. }\end{array}$ \\
\hline $\begin{array}{l}\text { Schouws } \\
\text { et } \mathrm{al}^{24}\end{array}$ & $\begin{array}{l}\text { Cross- } \\
\text { sectional }\end{array}$ & $\begin{array}{l}\mathrm{N}=10 \mathrm{I} \text { patients } \\
\text { with } \mathrm{BD} \\
>60 \text { years } \\
\text { (mean age: } 67.8 \text { ) }\end{array}$ & $\begin{array}{l}\text { MMSE was used to } \\
\text { provide an overall } \\
\text { assessment of cognitive } \\
\text { function. Self-reported } \\
\text { cognitive problems } \\
\text { were assessed through } \\
\text { "The Cognitive Failures } \\
\text { Questionnaire". All } \\
\text { subjects completed several } \\
\text { neuropsychological tests } \\
\text { grouped into five cognitive } \\
\text { domains: attention, } \\
\text { learning and memory, } \\
\text { visuoconstructional ability, } \\
\text { executive functioning and } \\
\text { verbal fluency }\end{array}$ & $\begin{array}{l}\text { To determine } \\
\text { whether subjective } \\
\text { cognitive complaints } \\
\text { were associated } \\
\text { with objective } \\
\text { neuropsychologic } \\
\text { performance and } \\
\text { to consider the } \\
\text { role of frontal lobe } \\
\text { dysfunction in the } \\
\text { awareness of cognitive } \\
\text { impairment }\end{array}$ & $\begin{array}{l}\text { Elderly bipolar patients had } \\
\text { no more subjective cognitive } \\
\text { complaints than comparison } \\
\text { subjects, whereas they showed } \\
\text { less cognitive functioning in several } \\
\text { domains. Having few subjective } \\
\text { cognitive complaints was associated } \\
\text { with poorer attentional and } \\
\text { executive functioning. } \\
\text { More than } 40 \% \text { of elderly bipolar } \\
\text { patients who were euthymic had } \\
\text { considerable subjective cognitive } \\
\text { complaints. }\end{array}$ \\
\hline $\begin{array}{l}\text { Sheeran } \\
\text { et } \mathrm{al}^{18}\end{array}$ & $\begin{array}{l}\text { Cross- } \\
\text { sectional }\end{array}$ & $\begin{array}{l}\mathrm{N}=50 \text { patients } \\
\text { with } \mathrm{BD} \\
\geq 60 \text { years }\end{array}$ & $\begin{array}{l}\text { Cognitive status was } \\
\text { assessed via the MMSE and } \\
\text { executive functioning was } \\
\text { assessed via the Initiation- } \\
\text { Perseveration subscale of } \\
\text { the DRS }\end{array}$ & $\begin{array}{l}\text { To conduct a } \\
\text { descriptive analysis of } \\
\text { geriatric and younger } \\
\text { adult residents } \\
\text { with BD or mania } \\
\text { in nonclinical adult } \\
\text { congregate facilities in } \\
\text { the greater New York } \\
\text { City region }\end{array}$ & $\begin{array}{l}\text { Comparing the two age groups, the } \\
\text { elderly sample had lower overall } \\
\text { cognitive status and executive } \\
\text { functioning, and were using a larger } \\
\text { number of medication classes than } \\
\text { the younger group. }\end{array}$ \\
\hline Smith et al $^{15}$ & $\begin{array}{l}\text { Cross- } \\
\text { sectional }\end{array}$ & $\begin{array}{l}\mathrm{N}=702 \text { patients } \\
\text { with } \mathrm{BD} \\
\geq 65 \text { years }\end{array}$ & $\begin{array}{l}\text { Data on the presence of } \\
32 \text { of the most common } \\
\text { chronic physical health } \\
\text { conditions }\end{array}$ & $\begin{array}{l}\text { To assess physical } \\
\text { comorbidities in BD } \\
\text { within primary care } \\
\text { and prescription } \\
\text { of cardiovascular } \\
\text { medications }\end{array}$ & $\begin{array}{l}\text { Prevalence was higher for bipolar } \\
\text { versus non-bipolar for viral hepatitis } \\
\text { (OR 5.69), constipation (OR } 3.37 \text { ), } \\
\text { and Parkinson's disease (OR } 3.05 \text { ). } \\
\text { Bipolar patients with coronary } \\
\text { heart disease and bipolar patients } \\
\text { with hypertension were more } \\
\text { likely to be current smokers than } \\
\text { controls (OR I.55, OR I.87), less } \\
\text { likely to be on a statin (OR 0.69, } \\
\text { OR 0.82), more likely not to be } \\
\text { on a antihypertensive (OR } 2.08 \\
\text { OR I.70) and less likely to be on } \\
\text { two or more antihypertensive } \\
\text { medications (OR 0.46, OR 0.53). } \\
\text { Compared to controls, individuals } \\
\text { with BD were significantly less } \\
\text { likely to have no recorded physical } \\
\text { conditions, and significantly } \\
\text { more likely to have one or more } \\
\text { physical conditions. All P-values } \\
\text { were <0.002. }\end{array}$ \\
\hline
\end{tabular}


Table I (Continued)

\begin{tabular}{|c|c|c|c|c|c|}
\hline Authors & Design & Sample & $\begin{array}{l}\text { Measurements of } \\
\text { outcome }\end{array}$ & Objectives & Results \\
\hline$\overline{W u}$ et $a^{22}$ & $\begin{array}{l}\text { Cross- } \\
\text { sectional }\end{array}$ & $\begin{array}{l}\mathrm{N}=263 \text { patients } \\
\text { with } \mathrm{BD} \text { (mean } \\
\text { age: } 74 . \mathrm{I} \pm 8.6 \text { ) }\end{array}$ & $\begin{array}{l}\text { A conditional logistic } \\
\text { regression model was } \\
\text { performed using data from } \\
\text { a nationwide dataset }\end{array}$ & $\begin{array}{l}\text { To investigate whether } \\
\text { patients with BD were } \\
\text { at an increased risk for } \\
\text { developing dementia }\end{array}$ & $\begin{array}{l}\text { BD was significantly associated with } \\
\text { an increased risk of subsequent } \\
\text { dementia (aOR 4.32). A significantly } \\
\text { increased risk was observed in } \\
\text { subjects diagnosed with dementia } \\
\text { before the age of } 65 \text { years } \\
\text { (aOR 3.77). }\end{array}$ \\
\hline
\end{tabular}

Abbreviations: aOR, adjusted odds ratio; BD, bipolar disorder; BMI, body mass index; CDT, Clock Drawing Test; CVD, cardiovascular disease; DM, diabetes mellitus; DRS, Dementia Rating Scale; eGFR, estimated glomerular filtration rate; MDD, major depressive disorder; MINIplus, Mini International Neuropsychiatric Interview plus; MMSE, Mini Mental State Examination; NCl, National Confidential Inquiry into Suicide and Homicide by People with Mental Illness; NGAL, plasma neutrophil gelatinaseassociated lipocalin; OR, odds ratio; $T_{2} T R$, percentage of treatment time that serum lithium concentrations were above the therapeutic range; $T_{b} T R$, percentage of treatment time that serum lithium concentrations were below the therapeutic range; $T_{i} T R$, percentage of treatment time that serum lithium concentrations were in the therapeutic range; VFT, verbal fluency test; VGR, Variance Growth Rate; $\beta 2-M G$, beta-2 microglobulin.

comorbidity, ${ }^{2,7,15-18}$ two on suicide, ${ }^{19,20}$ six on cognitive impairment/dementia, ${ }^{21-26}$ and two on aspects related to pharmacological therapy in BD. ${ }^{27,28}$

\section{The additional burden in the elderly with BD \\ Comorbidity and impairment in the older BD population}

Elderly bipolar patients were more likely to be diagnosed with diabetes mellitus, ${ }^{2}$ cancer, ${ }^{7}$ thyroid disorders, ${ }^{2,15}$ and hypertension, ${ }^{2,7}$ compared to age-matched controls. One of the studies comparing comorbidities in bipolar versus nonbipolar subjects found a high prevalence of viral hepatitis and Parkinson's disease among older bipolar patients. ${ }^{15}$ A recent study reported that most of the elderly bipolar patients did not present psychiatric comorbidities, and those who did were mainly patients with early-onset BD. However, the majority of the patients $(81.2 \%)$ had various physical comorbidities. $^{2}$ A recent cross-sectional analysis found that elderly individuals with BD were significantly less likely to have no recorded physical conditions and significantly more likely to have one (odds ratio [OR] 1.27), two (OR 1.45), and three or more (OR 1.44) physical conditions compared to age-matched controls. ${ }^{15}$ The same study also reported that individuals with BD and coronary heart disease or hypertension were less likely to have a primary-care record and experienced much less intensive prescribing for these conditions and were treated less intensively compared to non-bipolar subjects. Another physical health problem observed to be highly prevalent was obesity. ${ }^{16}$ Findings from a longitudinal study examining the impact of obesity on comorbidity in BD showed that obese subjects were observed to be significantly more likely to report any new-onset medi- cal condition (OR 2.32), new-onset hypertension, arthritis, diabetes, and hyperlipidemia. ${ }^{17}$ There are indications that obesity independently predicts the accumulation of medical conditions among adults with BD. Results from a recent cross-sectional study showed that BD was independently associated with an increased risk of having a diagnosis of chronic pain conditions. ${ }^{17}$ This study investigated the rates of seven chronic, noncancer pain conditions in veterans with $\mathrm{BD}$, finding elevated rates of pain in these patients compared to controls. Patients with BD had significantly higher odds of having any pain condition (OR 1.83), as well as specific pain condition (adjusted odds ratios [aOR] ranging from 1.50 to 6.24). Elevated rates of chronic pain conditions were also reported by another recent cross-sectional study. ${ }^{15}$

$\mathrm{BD}$ is associated with an elevated risk of suicide and suicide mortality in $\mathrm{BD}$ has been estimated to be approximately nine times that of the general population. ${ }^{10}$ Elevated levels of suicide incidents in elderly persons with BD have also been documented by other studies, especially in those presenting a current mood episode. ${ }^{19}$ Mixed and depressive episodes of BD as well as major depression were found to be the most frequent diagnoses in elderly individuals committing suicide. The same study suggested that bipolar subjects with depressive episodes might have a greater risk of committing suicide than subjects with unipolar depression. Another study observed a considerable lower rate of suicides in the oldest group of patients compared to the middle age groups (25-64-year age groups) in which the highest rates of suicides were reported. The majority of suicides in the sample of bipolar patients took place at least 5 years after diagnosis. ${ }^{20}$ A possible high-risk group of bipolar patients with alcohol dependence, concomitant personality disorder, depression, and current or recent in-patient admission was also identified. ${ }^{20}$ 
Dementia and cognitive impairment in later life are common features of BD. Elderly people with BD have been reported to have an increased risk of stroke, dementia, and other cognitive impairments. ${ }^{9}$ Compared to non-BD subjects, euthymic older adults with BD have been found to perform worse on cognitive tests such as the Clock Drawing Test and the verbal fluency test, but not on the Mini Mental State Examination. ${ }^{21}$ Findings from a recent population-based study of older patients with BD suggested a positive association between the presence of a lifetime history of BD and an increased risk of developing dementia (aOR 4.07), even after controlling for pertinent risk factors. ${ }^{22}$ These subjects tended to develop dementia already in middle age (aOR 3.77). A recent longitudinal study investigated the neurocognitive performance in the elderly with $\mathrm{BD} .{ }^{23}$ At baseline and follow-up, the bipolar patients performed worse on all neurocognitive measures compared to the healthy elderly group, although the cognitive decline during this period was similar in both groups. The association between subjective complaints of cognition and objective neuropsychological performance has also been investigated. The results provided evidence for a clear association between few subjective complaints and poorer attentional and executive functioning in euthymic elderly bipolar patients. ${ }^{24}$ It is not clear whether $\mathrm{BD}$ and major depressive disorder (MDD) have similar or different cognitive profiles and levels of impairment in older age. Cognition in aged euthymic bipolar patients was compared with older adults with MDD by using multiple tests measuring different cognitive domains. ${ }^{25}$ The results showed that subjects with BD and MDD were impaired across all cognitive domains compared with controls, and this was remarkably so concerning information processing speed and executive function. Bipolar patients did worse than patients with MDD across all cognitive domains, despite protective effects of having a higher education and lower vascular burden. Cognitive abilities of older bipolar patients (BD-I) in euthymic state have also been compared with patients with schizophrenia in the same age range. ${ }^{26}$ Strikingly limited differences in cognitive performance between the community-living patients with schizophrenia and the bipolar patients were found. However, both groups were impaired compared to controls in terms of executive functions. In a descriptive study comparing a group of geriatric bipolar patients with a sample of younger bipolar patients, a remarkably significant cognitive impairment was found across age groups. The older patients were distinguished from the younger by having a lower overall cognitive and executive functioning. ${ }^{27}$

\section{Pharmacological therapy}

Alterations in pharmacokinetics and dynamics, increasing comorbidity, drug interactions, and the subsequent polypharmacy combined with functional and cognitive limitations related to aging condition the response to mood stabilizers, which is necessary to consider when prescribing medication. Previous evidence suggests that pharmacological treatment of BD may reduce not only suicide risk but also premature mortality from natural causes, such as respiratory and circulatory diseases. ${ }^{8}$ A recent study observed that most of the sample of elderly outpatients received surprisingly only pharmacological therapy rather than additional psychosocial interventions for $\mathrm{BD},{ }^{2}$ even though there is evidence that these interventions are effective, especially in early stages of the disease. ${ }^{29}$ An average of three different psychotropic medications were prescribed to the elderly patients. ${ }^{2}$ A similar need of polytherapy has previously been reported in late-life BD. ${ }^{30}$ As expected, antidepressants were more frequently prescribed to patients with BD-II than to patients with BD-I and twice as much to patients with an early-onset BD than to patients with late-onset $\mathrm{BD}$.

Lithium still remains a pharmacological cornerstone for the prevention of manic and depressive recurrences in BD. ${ }^{27}$ It has been previously suggested that lithium may also have neuroprotective abilities and may reduce the risk of developing dementia. ${ }^{31}$ In a recent longitudinal study, lithium treatment was not associated with cognitive decline. ${ }^{23}$ Considering the narrow therapeutic window of lithium and the well-known harmful adverse effects of chronic lithium intoxication, lithium concentration monitoring is considered to be essential. Pharmacological variability, comorbidities, and polypharmacy related to the aged could also result in instability of serum lithium concentrations. For instance, a variety of antihypertensives (thiazide diuretics, angiotensinconverting-enzyme inhibitors) and nonsteroidal anti-inflammatory agents, which are common medications in elderly patients, can increase lithium concentrations. ${ }^{32}$ However, a retrospective study which compared serum lithium concentrations of bipolar patients in different age groups concluded that age does not seem to be a determinant of serum lithium concentration instability as they found no significant difference between the age groups ${ }^{28}$ In the majority of patients on long-term lithium therapy, a decrease in urinary concentration ability is observed and chronic interstitial nephropathy may develop. A study assessing the long-term effect of lithium on kidney function compared older patients on longterm lithium therapy (with a mean of 16 years of treatment) with age-matched patients never exposed to lithium. ${ }^{27}$ They 
found that lithium treatment caused an impairment of kidney function reflected also by abnormal levels of novel markers of kidney injury such as plasma neutrophil gelatinase-associated lipocalin and urinary beta-2 microglobulin, the latter probably being a better predictor because it showed multiple clinical and biochemical correlations.

\section{Discussion}

The present review examined mainly specific clinical characteristics, common comorbid physical conditions, and cognitive dysfunction in elderly with $\mathrm{BD}$. The reviewed studies suggest that the burden of BD is not limited to higher disability and comorbidity, but is also reflected in earlier mortality. Comorbid cardiovascular diseases, suicide, and cancer have earlier been suggested as the leading causes of excess mortality among bipolar patients ${ }^{33}$ based on findings similar to those of the studies included in this review. The reviewed studies investigating medical comorbidities found many similarities to previous research, providing further evidence of high comorbidity in elderly patients with BD. Cardiovascular and respiratory conditions, type II diabetes, and endocrinological abnormalities have previously been reported as the most frequent comorbidities in bipolar elderly. ${ }^{10}$ In addition, Parkinson's disease and viral hepatitis were found to be highly prevalent. ${ }^{15}$ Although cardiovascular diseases were not particularly prevalent in the reviewed studies, several comorbidities well known as risk factors to cardiovascular disease, such as hypertension, diabetes, obesity, and alcohol abuse, were reported as highly prevalent among bipolar elderly compared to the elderly in general. These results underscore the importance of contemplating these risk factors when assessing and treating BD in elderly patients. Evidence for a systematic under-recognition and undertreatment of cardiovascular illnesses in primary medical care was also found, ${ }^{15}$ which has been mentioned previously. ${ }^{34}$ There are several possible reasons for this association. Mood episodes and/or low awareness of cardiovascular risk factors and associated symptoms could have resulted in lower attendance rate to the general practitioner. Additionally, individuals with BD frequently experience social isolation and lower levels of education, which are also associated with higher unmet need for treatment. We cannot rule out that the cardiovascular risk factors in these subjects may be overlooked by the general practitioners while engaging their attention toward their mental illness. An average of three to four medical comorbid conditions have previously been reported in elderly bipolar patients; ${ }^{10}$ similar findings are reported in the reviewed studies. A strong association between obesity and a high medical burden in BD was also observed ${ }^{16}$ suggesting that overweight is an additional burden in many elderly with BD. It is noteworthy to consider that treatment of obesity could potentially mitigate the psychiatric and medical burden of BD. Also, pain conditions were reported to be highly prevalent in bipolar elderly. ${ }^{15,17}$ This association has previously received little attention, despite being related to reduced quality of life among those with mental illness. Even though such an association may be caused by depressive symptoms, it demonstrates another clinical area of need for this population that is being overlooked. Chronic pain conditions have also been related to an increased suicide risk, an aspect that needs to be considered also in the approach of the elderly bipolar population. ${ }^{35}$ The extent to which chronic pain might impact mental health recovery remains to be investigated.

The association between cognitive dysfunction and BD was corroborated by findings in this review. The pathophysiology behind the relationship between $\mathrm{BD}$ and the subsequent development of dementia largely remains unclear. Many possible mechanisms may underlie cognitive deficits in older adults with BD, such as residual mood symptoms, structural brain abnormalities, long-term side effects of medications, adverse psychosocial conditions, and medical comorbidities. Bipolar elderly performed significantly worse on some screening tests of cognitive function, ${ }^{21}$ and a positive association between the presence of BD and an increased risk of developing dementia was found. ${ }^{22}$ The elderly, in particular, represented a heterogeneous group, suggesting that various causes of cognitive impairment may have played a role in its development, emphasizing the need for further investigation of the underlying neuropathophysiological and pathological mechanisms that connect BD and dementia. One of the studies reviewed compared older bipolar subjects with a group of non-BD patients matched for distinct degrees of cognitive impairment, providing greater evidence to the results. ${ }^{21}$ However, it is important to consider confounding factors that can bias the link between cognitive dysfunction and BD, such as educational level, a family history of dementia, and socioeconomic status. Even though data were statistically significant, the clinical meaning of these differences is uncertain. Results showed that older adults with BD exhibited worse cognitive functioning compared to healthy controls, regardless of comparable vascular risk factors. ${ }^{23}$ This implies that there may be inherent factors related to the disease process that results in cognitive impairment, and not simply a manifestation of vascular risk factors. Even though disease exacerbations are associated with increasing cognitive dysfunction, there is increasing 
evidence of a higher risk of permanent cognitive impairment in bipolar patients. It is important to underline that all of the reviewed studies regarding this topic compared only bipolar patients in euthymic state with controls. Another important finding was the relation between having few subjective complaints about cognition and poor attentional and executive functioning suggesting that impaired awareness of cognition might be a reflection of cognitive deterioration. If so, this may influence assessment and treatment of these individuals as poor perception of such function may compromise communication of symptoms and functional deficits. Subjects with BD were observed to have cognitive dysfunction comparable to patients with schizophrenia and they were also reported to be more impaired across all cognitive domains compared with patients with MDD. ${ }^{25,26}$ Recommendations to preserve cognitive function target known risk factors associated indirectly with cognitive decline, such as hypertension, hypercholesterolemia, and diabetes mellitus. The relative neglect of the management of severe medical comorbidity associated with $\mathrm{BD}$ is still a significant challenge.

The consensus regarding high suicide risk among elderly bipolar patients compared to elderly in general was also suggested by the studies included in our review. ${ }^{19}$ Although, the risk was found to be lower among older patients compared to middle-aged, ${ }^{20}$ which is consistent to previous findings. ${ }^{36}$ Nevertheless, the committed suicide rates are higher among the elderly in comparison with young people, ${ }^{37}$ an aspect not mentioned in the included studies in this review.

Long-term treatment with lithium is often indicated in BD, which means extensive monitoring is essential to minimize adverse effects. Due to age-related factors, age has been suggested as a determinant of serum lithium concentration instability, which may be one of several reasons why lower daily dosages of lithium have been used in older patients with BD. ${ }^{30}$ Findings in one recent study differed from this idea suggesting that age is not an indication to not initiate or discontinue lithium therapy. ${ }^{28}$ As lithium can be associated with nephropathy, kidney function should be assessed frequently. Novel markers of kidney injury were compared in one study, suggesting urinary beta- 2 microglobulin, a marker of tubular function, to be a better predictor than plasma neutrophil gelatinase-associated lipocalin. ${ }^{27}$ It remains to be seen if beta- 2 microglobulin can make a better marker of kidney function than estimated glomerular filtration rate.

There are limitations to consider in this review. As most of the included studies were cross-sectional analyses, causal relationship cannot be established. This highlights the importance of future longitudinal studies allowing inferences to be drawn about important characteristics of this population. Due to limited age criteria in our search, sample sizes of the included studies varied. Further, some cross-sectional studies used data from nationwide datasets with reasonably large samples while other study designs were longitudinal having smaller samples. However, given the relatively sparse number of longitudinal studies in the field the results from these studies contribute significantly to the current knowledge. We found that studies of psychiatric comorbidity in the reviewed age group were scarce. Few articles were identified within our searched timeframe; thus, this topic was not emphasized in the review. A global tendency in the reviewed articles was a lack of bipolar subtype specificity, which means that some of the findings may be more suitable for either BD-I or BD-II. This is a major problem in general as the prevalence of the two bipolar types is different, with BD-I being rather rare compared to BD-II. The majority of the studies are either European or North American and hence the findings reflect mainly the population in these areas. It would be interesting that future investigation on this topic would highlight the possible differences among bipolar subtype, sex, and ethnicity. There was a lack of recent studies published regarding pharmacotherapy and considering its essential role in BD treatment, it would be convenient for more empirical data concerning psychotropic medications in late-life BD.

\section{Conclusion and future perspective}

Our review supports what recent studies have suggested: there is a high burden of comorbidities in late-life BD and cognitive impairment is common. Individuals with the disorder have an elevated risk of being affected by several comorbid psychiatric and especially somatic disorders, and hence clinicians should be especially attentive to physical comorbidity and early signs of cognitive decline, which may decrease mortality and herald polytherapy and the dementia outcome. Bipolar elderly may be under-recorded and undertreated in primary medical care, particularly for cardiovascular comorbidity, which is one of the leading causes of excess mortality in BD; thus, improved recognition of $\mathrm{BD}$ and provision of primary medical care may effectively reduce mortality and cognitive decline among these patients. Integrated treatment focusing simultaneously on psychiatric and medical outcomes may offer substantial advantages over usual care, which is often fragmented. The review of the literature indicates that clinical characteristics between the elderly and the younger 
population differ, suggesting that the clinical assessment of each group should be different and adapted. The heterogeneity of function and comorbid symptoms in this group of elderly bipolar patients clearly shows that it is important to highlight the need of an individual approach to each patient.

\section{Disclosure}

The authors report no conflicts of interest in this work.

\section{References}

1. American Psychiatric Association. Diagnostic and Statistical Manual of Mental Disorders. 5th. ed. Washington, DC: American Psychiatric Association; 2013.

2. Montes JM, Alegria A, Garcia-Lopez A, et al. Understanding bipolar disorder in late life. J Nerv Ment Dis. 2013;201(8):674-679.

3. Sajatovic M, Blow FC, Ignacio RV, Kales HC. Age-related modifiers of clinical presentation and health service use among veterans with bipolar disorder. Psychiatr Serv. 2004;55(9):1014-1021.

4. Dell'Aglio Jr JC, Basso LA, Argimon I, Arteche A. Systematic review of the prevalence of bipolar disorder and bipolar spectrum disorders in population-based studies. Trends Psychiatry Psychother. 2013;35(2):99-105.

5. Kessler RC, Ormel J, Petukhova M, et al. Development of lifetime comorbidity in the World Health Organization world mental health surveys. Arch Gen Psychiatry. 2011;68(1):90-100.

6. Merikangas KR, Jin R, He J-P, et al. Prevalence and correlates of bipolar spectrum disorder in the world mental health survey initiative. Arch Gen Psychiatry. 2011;68(3):241-251.

7. Kodesh A, Goldshtein I, Gelkopf M, Goren I, Chodick G, Shalev V. Epidemiology and comorbidity of severe mental illnesses in the community: findings from a computerized mental health registry in a large Israeli health organization. Soc Psychiatry Psychiatr Epidemiol. 2012;47(11): 1775-1782.

8. Tsai SY, Lee CH, Kuo CJ, Chen CC. A retrospective analysis of risk and protective factors for natural death in bipolar disorder. $J$ Clin Psychiatry. 2005;66(12):1586-1591.

9. Sajatovic M, Forester BP, Gildengers A, Mulsant BH. Aging changes and medical complexity in late-life bipolar disorder: emerging research findings that may help advance care. Neuropsychiatry (London). 2013; 3(6):621-633.

10. Lala SV, Sajatovic M. Medical and psychiatric comorbidities among elderly individuals with bipolar disorder: a literature review. J Geriatr Psychiatry Neurol. 2012;25(1):20-25.

11. Kilbourne AM, Post EP, Nossek A, et al. Service delivery in older patients with bipolar disorder: a review and development of a medical care model. Bipolar Disord. 2008;10(6):672-683.

12. Krishnan KR. Psychiatric and medical comorbidities of bipolar disorder. Psychosom Med. 2005;67(1):1-8.

13. Kemp DE, Gao K, Chan PK, Ganocy SJ, Findling RL, Calabrese JR. Medical comorbidity in bipolar disorder: relationship between illnesses of the endocrine/metabolic system and treatment outcome. Bipolar Disord. 2010;12(4):404-413.

14. Button KS, Ioannidis JPA, Mokrysz C, et al. Power failure: why small sample size undermines the reliability of neuroscience. Nat Rev Neurosci. 2013;14(5):365-376.

15. Smith DJ, Martin D, McLean G, Langan J, Guthrie B, Mercer SW. Multimorbidity in bipolar disorder and undertreatment of cardiovascular disease: a cross sectional study. BMC Med. 2013;11:263.

16. Goldstein BI, Liu SM, Schaffer A, Sala R, Blanco C. Obesity and the three-year longitudinal course of bipolar disorder. Bipolar Disord. 2013; 15(3):284-293.
17. Birgenheir DG, Ilgen MA, Bohnert ASB, et al. Pain conditions among veterans with schizophrenia or bipolar disorder. Gen Hosp Psychiatry. 2013;35(5):480-484.

18. Sheeran T, Greenberg RL, Davan LA, Dealy JA, Young RC, Bruce ML. A descriptive study of older bipolar disorder residents living in New York City's adult congregate facilities. Bipolar Disord. 2012; 14(7):756-763.

19. Ciulla L, Lopes Nogueira E, da Silva Filho IG, et al. Suicide risk in the elderly: Data from Brazilian public health care program. J Affect Disord. 2013;152-154:513-516.

20. Clements C, Morriss R, Jones S, Peters S, Roberts C, Kapur N. Suicide in bipolar disorder in a national English sample, 1996-2009: frequency, trends and characteristics. Psychol Med. 2013;43(12):2593-2602.

21. Aprahamian I, Ladeira RB, Diniz BS, Forlenza OV, Nunes PV. Cognitive impairment in euthymic older adults with bipolar disorder: a controlled study using cognitive screening tests. Am J Geriatr Psychiatry. 2014;22(4):389-397.

22. Wu KY, Chang CM, Liang HY, et al. Increased risk of developing dementia in patients with bipolar disorder: a nested matched casecontrol study. Bipolar Disord. 2013;15(7):787-794.

23. Schouws SN, Stek ML, Comijs HC, Dols A, Beekman AT. Cognitive decline in elderly bipolar disorder patients: a follow-up study. Bipolar Disord. 2012;14(7):749-755.

24. Schouws SNTM, Comijs HC, Stek ML, Beekman ATF. Self-reported cognitive complaints in elderly bipolar patients. Am J Geriatr Psychiatry. 2012;20(8):700-706.

25. Gildengers AG, Butters MA, Chisholm D, et al. Cognition in older adults with bipolar disorder versus major depressive disorder. Bipolar Disord. 2012;14(2):198-205.

26. Meesters PD, Schouws S, Stek M, et al. Cognitive impairment in late life schizophrenia and bipolar I disorder. Int J Geriatr Psychiatry. 2013;28(1):82-90.

27. Rybakowski JK, Abramowicz M, Chłopocka-Wozniak M, Czekalski S. Novel markers of kidney injury in bipolar patients on long-term lithium treatment. Hum Psychopharmacol. 2013;28(6):615-618.

28. van Melick EJ, Souverein PC, den Breeijen JH, Tusveld CE, Egberts TCG, Wilting I. Age as a determinant of instability of serum lithium concentrations. 2013;35(5):643-648.

29. Vieta E, Pacchiarotti I, Valentí M, Berk L, Scott J, Colom F. A critical update on psychological interventions for bipolar disorders. Curr Psychiatry Rep. 2009;11(6):494-502.

30. Al Jurdi RK, Marangell LB, Petersen NJ, Martinez M, Gyulai L, Sajatovic M. Prescription patterns of psychotropic medications in elderly compared with younger participants who achieved a "recovered" status in the systematic treatment enhancement program for bipolar disorder. Am J Geriatr Psychiatry. 2008;16(11):922-933.

31. Kessing LV, Forman JL, Andersen PK. Does lithium protect against dementia? Bipolar Disord. 2010;12:87-94.

32. Dunner DL. Drug interactions of lithium and other antimanic/moodstabilizing medications. J Clin Psychiatry. 2003;64(Suppl 5):38-43.

33. Leboyer MDJK. Bipolar disorder: new perspectives in health care and prevention. J Clin Psychiatry. 2010;71(12):1689-1695.

34. Carney CP, Jones LE. Medical comorbidity in women and men with bipolar disorders: a population-based controlled study. Psychosom Med. 2006;68(5):684-691.

35. Hassett AL, Aquino JK, Ilgen MA. The risk of suicide mortality in chronic pain patients. Curr Pain Headache Rep. 2014;18(8):436.

36. Vasudev A, Thomas A. "Bipolar disorder" in the elderly: What's in a name? Maturitas. 2010;66(3):231-235.

37. Pritchard C, Amanullah S. An analysis of suicide and undetermined deaths in 17 predominantly Islamic countries contrasted with the UK. Psychol Med. 2006;37(03):421. 


\section{Publish your work in this journal}

Neuropsychiatric Disease and Treatment is an international, peerreviewed journal of clinical therapeutics and pharmacology focusing on concise rapid reporting of clinical or pre-clinical studies on a range of neuropsychiatric and neurological disorders. This journal is indexed on PubMed Central, the 'PsycINFO' database and CAS, and is the official journal of The International Neuropsychiatric Association (INA). The manuscript management system is completely online and includes a very quick and fair peer-review system, which is all easy to use. Visit http://www.dovepress.com/testimonials.php to read real quotes from published authors.

\footnotetext{
Submit your manuscript here: http://www.dovepress.com/neuropsychiatric-disease-and-treatment-journal
} 